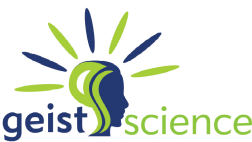

Journal of Education \& Social Sciences

ISSN: 2410-5767 (Online)

ISSN: 2414-8091 (Print)

\title{
A Case Study on Quality of Education in the
} Trust School, Lahore

\section{Affiliation:}

Nauman Ahmed Abdullah

Lecturer (Education), Virtual University of Pakistan.

E-mail: nauman101@hotmail.com

Tuiba Ikram

MPhil Scholar, University of Gujrat, Lahore.

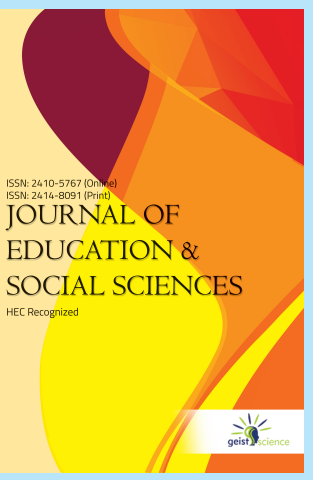

\section{Manuscript Information}

Submission Date: August 20, 2019

Acceptance Date: October 24, 2019

Publication Date: November 24, 2019

Citation in APA Style:

Abdullah, N. A., \& Ikram, T. (2019). A Case Study on Quality of Education in the Trust School, Lahore, Journal of Education \& Social Sciences, 7(2), 18-37.

DOI: https://doi.org/10.20547/jess0721907202 


\title{
A Case Study on Quality of Education in the Trust School, Lahore
}

\author{
Nauman Ahmed Abdullah * $\quad$ Tuiba Ikram ${ }^{\dagger}$
}

\begin{abstract}
Over the last few decades quality of education has been given special attention in the academic world. After many reforms and efforts, Pakistan still lags in providing quality education. However, some private school systems are making good efforts in providing quality education and that too at affordable fees. The Trust School is one of this kind and in a short span of time it has achieved a significant position among quality driven schools. The purpose of this research was to study the quality of education provided by The Trust School in detail. For that, the researchers took case study design to take into account all the aspects of the "Trust school". Using exploratory case study design, the researchers used triangulation of the data sources including principals/heads, teachers and class teachers, students of class 9 th and 10th, and previous board examination results of "Trust School" students to understand the phenomenon of quality of education.Semi-structured interviews, close ended questionnaires, and observation checklists were developed by the researchers after a comprehensive review of the literature; all these were validated through expert opinion evidence. thematic description approach analysis on qualitative data and descriptive statistical techniques on quantitative data revealed different factors that played a role providing quality of education. The results of this research have implications for understanding why and how to provide quality education and the dissemination of this case study can serve as a model for other schools to replicate it for providing and maintaining quality of education.
\end{abstract}

Keywords: Quality, education, trust school, case study.

\section{Introduction}

Quality education is a subject of worldwide interest to all stakeholders. Educationists, policy makers, parents, and students are all associated with quality education in one way or the other. The importance of quality education is that it makes the student academically and formatively stable and instructs the understudy in turning into dynamic and beneficial individuals in the society (McLean, Bond, \& Nicholson, 2015). A Quality Education is not one that is measured absolutely by a test score or by what number of words every moment a 5-year-old can read. To behold back to these streamlined estimations is to do an insult to both the understudy and the expression quality education itself (Mehrotra, 2006).

A quality education gives assets and guides arrangement to guarantee that every child enters school solid and finds out about and rehearses a sound way of life; learns in a domain that is physically and candidly okay for understudies and grown-ups (Colbert \& Arboleda, 2016). Student is effectively occupied with learning and is associated with the

\footnotetext{
*Lecturer (Education), Virtual University of Pakistan. E-mail: nauman101@hotmail.com

${ }^{\dagger}$ MPhil Scholar, University of Gujrat, Lahore.
} 
school and more extensive group; has admittance to customized learning and is upheld by qualified, mindful grown-ups; and is tested scholastically and arranged for accomplishment in school or further study and for work and support in a worldwide situation (McCowan, 2013).

A quality instruction gives the results expected to people, groups, and social orders to succeed. It permits schools to adjust and coordinate completely to their groups and get to a scope of administrations crosswise over areas intended to strengthen the instructive improvement of their understudies (Whitty, 2000). A quality instruction is strengthened by three key columns: guaranteeing access to quality educators; giving utilization of value learning devices and expert improvement; and the foundation of sheltered and steady quality learning situations (Basit, 2003).

Dr. Edward Deming is generally recognized as the father of quality. He was the first to introduce the basic tents of traditional management principles. He deemed the traditional motivation system to be degrading and economically unproductive. Under that system, work incentives were linked with piece of work to maximize worker output, followed by an inspection process in which defective items were subtracted from the worker piece work credit (Denzin \& Lincoln, 2011). Quality means degree of excellence of a product or service provider. Quality is very difficult to define. It is often used as synonym for excellence. Quality is single most important issue in education, business and government today. Issues of quality in education have been a matter of interest and concern for some time in different institutions, systems and countries. Saying something clear and comprehensive about that elusive concept has, however proved for some difficult (Campbell, 1997). Wherever we encounter quality we have no problem recognizing it, but if anyone asks us to define or describe it, suddenly we are in trouble. Quality and time are protean terms. They defy precise specification and are recalcitrant to or more persistent attempts to analyze them (Delyser, 2008).

Elliott and Williams (2001) argued that quality can be defined as what best satisfies and exceeds customers' needs and wants; this is sometimes called quality in perception. LeCompte (2000) argues that quality is related to a body of knowledge about products, services and customers and client satisfaction. The term is not a synonym for excellence or goodness. Quality does not mean up market (quality car, quality food) therefore perspective is important.

\section{Quality Indicators}

Liston (2013) said that regarding key elements in defining quality approach one must focus on;

- Identifying and satisfying client needs

- Developing and taping the full potential of staff

- Improving key processes 
According to Roberts (2013) the above mentioned elements are the indicators of quality education. Saeed (2003) identified the following quality indicators in the literature; (1) Self-Evaluation and Development (2) Information (3) Comparison (4) School Context and Profile (5) Teaching and Learning Process (6) Personal Growth and Development (7) Subject Balance (8) Language Policy (9) Syllabi.

The question of how quality education is to be secured and in what most cost efficient manner is an issue of major concern in countries around the world. A distinctive feature of recent education reforms in New Zealand, for example, has been the attempt to combine structural changes of minimalist kind with maintenance of quality goals. This is particularly evident in New Zealand's efforts to provide increased support for schools with large numbers of pupils from low income families and in endeavors to promote gender and racial equality in all aspects of schooling (Franklin, 1997). This, whilst the reforms efforts in New Zealand, originally driven by a labor government, appear to exhibit considerable similarities to the conservative governments reforms in England and wales, significant differences in priorities and structural arrangements can be discussed in response to high priority given by New Zealand government to matters of equity and social justice. In France and most Scandinavian countries, the provision of a structurally uniform and homogeneously organized system of schooling has been seen traditionally as a means of providing quality and equal access to all (Mehrotra, 2006).

\section{National Education Policy 2009 and Quality of Education}

The national education policy 2009 also laid stress on quality of education. The major focus of the policy was on the following things. Widen access to education for all and to improve the quality of education, particularly in its dimension of being relevant to the needs of the economy. Equalize access to education through provision of special facilities for girls and boys alike, under-privileged/marginalized groups and handicapped children and adults. To eradicate illiteracy within the shortest possible time through universalizing of quality elementary education coupled with institutionalized adult literacy programs (Malik \& Courtney, 2011).

In Pakistan, with so many options available, in public and private sector, for parents to select a school for their children, quality of education becomes a fundamental question in the selection. In private sector there again is an element of selection from the chain school systems, elite class schools, or commoner schools with good student achievement results. Akram and Shah (2018) explained different factors contributing in the students' achievement and termed it as quality indicator. With majority of Pakistani population belonging to middle class, very limited options are there for such parents to select a school ensuring quality of education. In the recent years, Trust school has won the confidence of parents in becoming their possible choice for schooling of their children. Based on its economical fee packages along with scholarships and other privileges, and good academic results in the board examination, Trust school has been able to expand in the society. 


\section{Trust for Education and Development of Deserving Students (TEDDS)}

Trust for Education and Development of Deserving Students (TEDDS) was established in 1993 by seven like minded people to advance quality training for exemplary meriting understudies. Today TEDDS has developed to an extensive welfare association wherein perpetually expanding number of understudies is profiting through its growing system of The Trust School in Lahore. It is a non-benefit association built up as per the Trust demonstration 1882 and is appropriately affirmed by Pakistan Center for Philanthropy (PCP). All the commitments to The Trust School are duty exempted (Kalam, 2003).

Trust for Education and Development of Deserving Students (TEDDS) is a non-business welfare Trust framed in 1993 and appropriately enlisted under Trust Act 1882 vide Registration No. 232-LH-VSWA dated June 04, 1993 (Arshad, 2003). The Trustees began The Trust School with an unmistakable vision of taking upon the undertaking and duty of building up a perfect educational system where the underprivileged offspring of the Pakistani society will be cultivated and supported and can get the best quality training free and on truncated cost. The Trust School additionally gives preparation to its instructors with the goal that they could meet the difficulties of developing system of training on the planet. The arrangement of powerful educator preparing projects is for the expert development of the instructors and to advance quality training in Pakistan by contributing toward accomplishing its objective. For this situation contemplate specialist will explore the part of educators prior and then afterward instructors preparing program (Iqbal, 2004).

Therefore, this case study investigated the actual results and findings to measure the quality education in The Trust School. The provision of quality education is the basic responsibility of the schools. In our society quality education is very rare in schools. Many schools are providing normal education to the students they are focusing only on income of the schools not on the quality of education but there is an institution who is providing quality education to the students that is The Trust School. Trustees started The Trust School with a very clear vision of taking upon the task and responsibility of establishing an ideal school system where the underprivileged children of the Pakistani society will be fostered and nurtured and can get the best quality education free and on truncated price.

Researchers investigated the quality education in The Trust School that was provided by the teachers that too on low cost. The Trust School is paying attention on quality education with 'no profit no loss' therefore; this study investigated the quality education in The Trust School.

\section{Research Design}

Case study design was used to investigate the quality of education in "Trust school". Case study deals with every aspect of the phenomenon, it helps in collecting in-depth and detailed data (Creswell, 2012). Therefore, researchers had chosen a case study research design. This research was based on qualitative and quantitative research method. In this research quality education, students and teachers' behavior and teaching and learning 
process was observed which is best suitable under qualitative studies. This exploratory case study design collected information about quality education in The Trust School.

\section{Sampling Design}

The population included Principals, Headmasters/mistress, teachers, students, administration, of each branch as well as of Head office personnel of The Trust School. The details of branches are:

- The Trust School (Amir Town Branch)

- The Trust School (Thokar Niaz Baig Branch)

- The Trust School (Bagrian Branch)

- The Trust School (Green Town Branch)

- The Trust School (Sabzazar Branch)

- The Trust School (Wapda Town Branch)

- Head office

Researchers collected data from all these sources to deeply understand how The Trust School ensures continuous quality education. Researchers investigated the implementation of rules for providing quality education in all branches of The Trust School. Purposive sampling technique was used to collect the data from the participants. Data were collected from 6 principals/headmasters/mistresses, 52 teachers, and 21 students. Observation check list was also used by the researchers to observe the actual situation in The Trust School. Data were collected on the instruments developed by the researchers themself.

\section{Instrumentation}

There were four instruments to check the quality of education in "Trust school" which were used for data collection.

- Interviews (semi-structured) from principals / headmasters/mistresses

- Interviews (semi-structured) from teachers of 9 th and 10th class

- Questionnaires (close ended) for students 9th and 10th class, and

- Observation checklist for researchers

The content validity of these instruments (interviews, questionnaire and observation checklist) were ensured through taking expert opinions of two university teachers, three school teachers, and one principal of a school. After ensuring the evidence of content validity the questionnaire were also piloted and reviewed by an English language expert 
to ascertain correct use of English language. The pilot study of questionnaire and observation checklist reported internal consistency reliability was 0.81 and 0.76 respectively on coefficient of Cronbach Alpha.

\section{Ethical Considerations}

Ethical considerations in terms of anonymity of participants and branches were ensured during the data collection process. Prior appointments for interviews were taken from the participants, they were given the interview questions in advance and after taking their consents the interviews were recorded and the recordings were also shared with them upon request.

\section{Results of the Trust School In Previous Matriculation Examinations}

\begin{tabular}{|c|c|c|c|c|c|c|}
\hline \multirow{2}{*}{ Year } & \multirow{2}{*}{ No. of Students } & \multicolumn{4}{|c|}{ GRADES } & \multirow[t]{2}{*}{ Result \% } \\
\hline & & $\mathrm{A}+$ & A & B & C & \\
\hline 2016 & 297 & 201 & 70 & 25 & 1 & $100 \%$ \\
\hline 2015 & 214 & 159 & 47 & 8 & - & $100 \%$ \\
\hline 2014 & 158 & 88 & 46 & 22 & 2 & $100 \%$ \\
\hline 2013 & 124 & 74 & 39 & 11 & - & $100 \%$ \\
\hline 2012 & 115 & 70 & 36 & 9 & - & $100 \%$ \\
\hline 2011 & 137 & 107 & 29 & 1 & - & $100 \%$ \\
\hline 2010 & 104 & 85 & 19 & - & - & $100 \%$ \\
\hline 2009 & 145 & 128 & 16 & 1 & - & $100 \%$ \\
\hline 2008 & 97 & 94 & 3 & - & - & $100 \%$ \\
\hline 2007 & 95 & 91 & 4 & - & - & $100 \%$ \\
\hline 2006 & 92 & 77 & 15 & - & - & $100 \%$ \\
\hline 2005 & 32 & 30 & 2 & - & - & $100 \%$ \\
\hline 2004 & 45 & 19 & 24 & 2 & - & $100 \%$ \\
\hline 2003 & 63 & 63 & 48 & 15 & - & $100 \%$ \\
\hline 2002 & 34 & 24 & 9 & 1 & - & $100 \%$ \\
\hline 2001 & 50 & 40 & 9 & 1 & - & $100 \%$ \\
\hline
\end{tabular}

The board examination results of the "Trust school" showed that since their first batch in the board examination they have maintained 100\% results. Moreover, an interesting fact seen in the table above was that there was an increase in the number of students with every coming year. This also reflected the confidence of parents in sending their kids to the Trust school. Majority of the students secured A and A+ grades. In the history of 16 years only 3 students have secured $C$ grade in external examination. That further strengthened the researchers claim that quality of academic excellence is provided by the Trust school. 


\section{Results}

The data from the multiple sources were collected, analyzed using appropriate statistical analysis techniques. For semi-structured interviews of heads/ principals, and teachers and class teachers the researchers used Thematic Description Approach which is considered suitable for qualitative data analysis especially in interviews (Creswell, 2012). The interviews were recorded with prior consent of the participants. The recordings were transcribed and then themes were identified for each question separately. The data collected from students through close ended questionnaires were measured at a yes/no checklist. Descriptive statistical techniques were used on that data e.g. percentages and frequency. For the detailed investigation of factors the results are presented separately for heads/principals, teachers and head teachers, and students.

\section{Principals/Headmaster/Mistress Data Analysis}

Participants were given codes as $\mathrm{H} 1$ for headmaster/mistress 1, H2 for headmaster/mistress 2, H3 for headmaster/mistress $3 \mathrm{H} 4$, for headmaster/mistress 4, H5 for headmaster/mistress 5 , and $\mathrm{H} 6$ for headmaster/mistress 6 . This was in line with the ethical consideration of the study. A total of six principals/headmasters were selected, one from each branch. Their detail analysis, question wise is given below.

The participants were asked that how did Trust school provide quality of education. The participants answered in the following way. The participants pointed out the following factors physical facilities / resources (H1), holistic child development approach (H2, H3), 360 degree approach (H4, H5), and modern techniques of teaching (H6).

The next question was what factors did you see of this quality education? Three participants (H1, H2 and $\mathrm{H} 4)$ reckoned qualified teachers, student teacher ratio, activity based teaching, modern and effective teaching methodology, good infrastructure, conducive environment, use of AV aids, modern curriculum and participatory leadership, as the key factors. Other factors were equity, child centered teaching and learning, result oriented approach (H3), reinforcement, repetition of concepts (H5, H6).

The participants were inquired what type of efforts institution put to improve learning of students, in response to this question participants told that conducive environment, mentoring and optimal class size (H1), broad vision, and feedback of results $(\mathrm{H} 2)$ to be important. While participant H3, H5 and H6 considered that informational documentaries, different field trips and activities for students, as significant. One participant (H4) responded that special classes are organized for weak students to improve their learning. Students are given sample time to discuss their difficulties regarding learning of different subjects and teachers tried to solve their learning difficulties.

When a question was asked related to how did teacher's provide quality education. Following responses of students were reported. Three participants $(\mathrm{H} 1, \mathrm{H} 2$ and $\mathrm{H} 4)$ rated that different AV aids, active teaching, while (H3) expressed that activity based teaching and (H5) valued, student centered approach, and in the views of (H6) ,different workshops kept teachers up-to date with modern knowledge was the reason how teachers were able to provide quality of education. The participants were questioned about 
what type of teaching method were you following for quality education? All participants replied that different methods ranging but no limited to lecture method, discussion method, heuristic method, analytics method, synthetic method, inductive method, deductive method; problem solving method, project method, and activity method are used to teach the students in school. Project and activity method are emphasized in "Trust school" because these methods may check the overall academic development of the students.

The next question was asked from the participants about what type of examination system was there in your school? The participants answered as listed below. The participants (H1, H2 and $\mathrm{H} 5)$ said that formative assessment plays a major role in assessing the performance of the students. The participants (H3 and $\mathrm{H} 4)$ said that summative assessment is also used alongside of formative assessment. The participant (H6) said that diagnostic assessment is also used because it is used whenever students are facing difficulties in learning. The participants were enquired about how did you train students to avoid cheating. The participants gave their response in the following way.

The participants (H1, H5 and H6) said that the moral training and character building were emphasized in "Trust school". The participants (H2, H3 and H4) narrated that the behavior of the students were observed and checked strictly on daily basis with the purpose to maintain the discipline in the class. The next question was asked from the participants about how and what did you check about students at the time of admission. The participants answered in this way.

According to H1, H3, H4, H5, and H6 the Trust School checked the basic knowledge of students by taking test in English, Urdu and Mathematics at the time of admission. Those students who got $50 \%$ or more numbers in this entrance test are offered admissions. The participant (H2) said that a fair and transparent assessment was used at the time of admission in the "Trust school". The participants were questioned about what were the facilities provided by the institution to the teachers? The participant expressed these factors i.e. selection on merit, attractive salary packages, decision making, annual increment, free of cost training and workshops, seminars, pick and drop service and incentives. One participant (H5) said that The Trust school provide competitive environment for the professional growth of the teachers. Different types of training workshops and seminars are also conducted to train the teachers to enhance their professional skills.

The participants were asked that what were the techniques used by the institution to improve slow learners? All participants said that extra classes were arranged for slow learners. The teachers arranged group activities for slow learner students. The concepts are repeated in front of students. One of the participant (H3) said that concerned teachers arrange group and peer learning for slow learning students. The participants were enquired about were the teachers putting efforts after school for quality education. The participants answered in this way. All participants said that their teachers put efforts to improve the learning environment of school. One participant (H5) said that they recruit teachers in their schools after a rigorous procedure. These teachers are academically very sound and they have professional experience. They put their efforts to improve the quality of education in school. 


\section{Teachers' Data Analysis}

For the triangulation and enrichment of data, teachers were interviewed. Ten male and ten female teachers were selected purposively from 9th class and 10th class, separately. Each male and female class teacher of class 5, 6, 7, 8, 9, and 10 were also selected to get the data in detail. A total of 52 teachers (10 male from class 9, 10 male from class 10, 10 female from class 9, 10 female from class 10, and male class teachers of class 5, 6, 7, 8, 9 , and 10, and female class teachers of class $5,6,7,8,9$, and 10) were interviewed and their responses were noted down on the interview notes. Teachers were asked questions about facilities provided by school, teacher training, teaching methodology, curriculum and leave rule. The responses of the teachers were analyzed using thematic description approach as discussed above. Themes from the answers were identified and given codes, then interpreted heading wise.

\section{Male and Female Teachers (9th and 10th Class) and Class Teachers (5 to 10 class)}

The teachers were coded separately for male and female of class 9th and 10th and class teachers of class 5 to 10 were coded separately. In actual research the data were analyzed separately and then compared with each other. However, in this paper the analysis of interviews of all the sampled participant teachers is grouped together for comparison of views and better interpretation of results. Following were the codes given.

For male teachers of class nine 9MT i.e. 9th class male teacher, followed by the number of teacher. e.g. 9MT1 for male teacher 1 of 9 th class male teachers, 9MT2, for 9th class male teacher 2, and so on. For female teachers 9FT i.e. 9th class female teacher followed by the teacher number. E.g. 9FT1 for teacher 1 for 9 th class female teacher 1 , and so on up to teacher number 10 . For male teachers of 10th class code was $10 \mathrm{MT}$ followed by the teacher number, e.g. 9MT9 for male teacher 9 of class 9th. Likewise for female teachers of class 10 the code was 10FT followed by the teacher number, e.g. 9FT8 for female teacher 8 of class 9 th.

Class teachers were coded as MCT5 for male class teacher of class 5, MCT6 for male class teacher of class 6, MCT7, MCT8, MCT9, MCT10 for male class teacher of class 7, 8, 9 , and 10 respectively. Similarly, female class teachers were given codes as FCT5, FCT6, FCT7, FCT8, FCT9, and FCT10 FOR female class teachers of class 5, 6, 7, 8, 9, and 10 respectively. Given below is question wise analysis of all sub groups of teachers.

\section{Facilities Provided By School}

All the participants male and female teachers of class 9 and 10 said that school did not provide them the facility of travelling form their home to the school neither any opportunity of getting higher education. However, one male class teacher of class 8 (MCT8) having experience of 9 years with the school was of the view that the facility of travelling from home to school was provided two years ago from the school. Furthermore,five female and four male participants from class 9 and six female participants from class 10 
and seven male participants from class 10 explained that they did not get a chance to visit other branches of "Trust school" during the school hours while five participants narrated that they visit to other branches of "Trust school" during school hour to interact with staff for their professional growth. It was observed that only head teachers/class teachers had the provision to visit other branches, as they were subject specialists and expert in their fields.

\section{Teacher Training}

Eight male and nine female participants from class 9, and all male and female teachers from class 10, and all male and female class teachers agreed that different computer competitions, computer courses, block printing and workshops were held as a part of refresher courses which helped in the teacher training. Two participants (9MT3, 9MT8) responded that the computer courses offer in the "Trust school" do not fill modern needs of the teachers. One female participant (9FT2) narrated that cooking courses are also offered in the "Trust school" especially for females. One participant (10MT4) narrated that Pedagogical based courses are also offered in school to train the teachers and equip them with modern techniques. All participants explained that they used pictures, models, charts, projectors and diagrams while others (9MT1, 9MT4, 9FT6, and MCT7) narrated. They use flash cards and videos as AV aids in the classroom. Three participants (10FT3, 10FT5 and 10FT8) said that they use information technology as teaching material. All participants responded that school management was providing all the material using in teaching. However one participant (9FT7) narrated that she arranges teaching material herself because school did not provide teaching material, while one participant (10MT6) narrated that divisional in-charge is providing the teaching material to the school.

\section{Teaching Methodology}

Upon asking the different teaching methodologies participants responded with various methodologies. Most commonly quoted of those were, lecture method, discussion method, activity method, storytelling method, synthetic method, heuristic method and inductive and deductive method to teach the students. One participant (9MT7) explained that he use play way method and brain storming method to teach the students. Three participants (9FT2, 9FT4 and 9FT7) narrated that they use project method, problem solving method and question answer method to teach the student. One participant (MCT9) reported that he uses teaching method according to the nature of the topic. Nine participants responded that they used internet as source of technology to teach the material. One participant (9MT8) narrated that he plans to use technology for teaching material according to the required activity.

Two participants (9MT2 and 9MT6) said that debate competitions were held in school. Five participants responded that quiz competition were organized by school. Three participants (9MT2, 9MT5 and 9MT8) narrated that workshops are organized as a part of curricular activities for teacher. One participant (10MT7) narrated, training workshops and seminars are held by the school administration to train the teachers. Two female 
participants (9FT5 and 9FT9) responded that quiz and debate competition are held for teachers to train the teachers. All the participants said that they were given extra tasks at home for tomorrow teaching in the school. They had to develop lesson plan for teaching in the classroom. It was noticed, however, that the class teachers had some additional tasks on their hands.

\section{Curriculum}

As far as course book is concerned the participants narrated that school provides the book only. Nine participants said that The Trust School do not provide books or any other type of material while one participant (FCT8) responded that The "Trust school" provide color marker, line models, charts and paper to the teachers to be more effective. All participants said that they checked note books according to the specific criteria and this criterion is provided by school to improve the quality of education. All the participants explained that they marked the note book according to the specific criteria given by their school. It was discovered that in lower or up to 8th class the syllabus of oxford was offered parallel with the syllabus of Punjab textbook and curriculum wing and in 9th and 10th only Punjab textbook and curriculum wing books were offered.

\section{Leave Rules}

Majority (32) of teachers responded that there was no effect on the learning of the students when they took leave because a substitute teacher was always there to teach the students on their place. Five teachers (9MT1. 9FT3, 9MT4, MC107, and 10FT7) narrated that there is direct effect on the learning of the students if they take leave. One participant (9FT10) responded that the studies of the students is affected to some extent if the teacher is absent from the school. Another participant (10FT5) narrated that the learning of the student is affected a little bit if they take leave from the school. All the participants said that they had to inform the school administration before taking off from the school. School management showed flexibility most of the time if the teachers were on leave due to genuine reason. One participant (10MT3) said that they need to inform the school management before taking leave. However, there were mixed opinions of participants relating to their own leave from the duty. Two participants (MCT8 and MCT10) narrated that teachers are struck off from school after three explanations. Five female class teachers were of the view that the struck off rule practiced by the school was very strict. One participant (FCT9) narrated, The school may strike off any person depending upon different reasons.

\section{Data Analysis of Student (9th and 10th Class)}

From students section, this research took 10 students from class 9 and 11 students from class 10. Their views were taken on a yes/ no scale with items that were gone through validity check of expert opinion. Frequencies and percentages were calculated on the responses of the students. 
Table 2 indicated the responses of 9th and 10th class students about different aspects related to the quality of education in the Trust School. All students said that there was a tradition of showing papers to them after the exams. The students $(100 \%)$ responded that they were satisfied with the teaching of the teachers. The students $(100 \%)$ reported that there was a tradition of reporting the performance of students in studies to their parents. However, in class 10th only two students answered in negative on this item. The students $(100 \%)$ of class 9 responded that they were facilitated with the educational resources used in their studies, only one student from class 9 rated it in negative. The students $(100 \%)$ narrated that they were regular and punctual. This was because of the strict rules being followed through the school regarding attendance of the students and even more check and balance was ascertained on 9th and 10th class students. The students of 9th and 10th said that they were taking interest in studies, with only exception of a student of class 10 th. $(100 \%$ students reported that there was a tradition of book fair in their school, they were satisfied with the teaching content, there was a discussion system in the class, there was a positive response of school management towards their new idea, they were free to elaborate their ideas in studies, the teachers admitted their mistakes after checking the papers, and they were satisfied with the content.

Table 2

Responses of 9th and 10th class students

\begin{tabular}{|c|c|c|c|c|c|c|c|c|c|}
\hline \multirow[t]{3}{*}{ Sr. } & \multirow[t]{3}{*}{ Statements } & \multicolumn{4}{|c|}{ 9th class students } & \multicolumn{4}{|c|}{ 10th class students } \\
\hline & & \multicolumn{2}{|c|}{ Yes } & \multicolumn{2}{|c|}{ No } & \multicolumn{2}{|c|}{ Yes } & \multicolumn{2}{|c|}{ No } \\
\hline & & $\mathrm{f}$ & $\%$ & $\mathrm{f}$ & $\%$ & $\mathrm{f}$ & $\%$ & $\mathrm{f}$ & $\%$ \\
\hline 1 & Is there any tradition to show papers after exams & 10 & 100 & 0 & 0 & 11 & 100 & 0 & 0 \\
\hline 2 & Are you satisfied with your teachers' teaching & 10 & 100 & 0 & 0 & 11 & 100 & 0 & 0 \\
\hline 3 & Is there any tradition to give feedback to parents about your studies & 10 & 100 & 0 & 0 & 9 & 81.8 & 2 & 18.2 \\
\hline 4 & Are you facilitated with educational sources used in studies & 10 & 100 & 0 & 0 & 10 & 90.9 & 1 & 9.1 \\
\hline 5 & Are you regular and Punctual & 10 & 100 & 0 & 0 & 11 & 100 & 0 & 0 \\
\hline 6 & Are you taking interest in teaching/ learning & 10 & 100 & 0 & 0 & 10 & 90.9 & 1 & 9.1 \\
\hline 7 & As there any tradition of book fair for studies & 10 & 100 & 0 & 0 & 11 & 100 & 0 & 0 \\
\hline 8 & Are you satisfied with teaching content & 10 & 100 & 0 & 0 & 11 & 100 & 0 & 0 \\
\hline 9 & Is there any discussion system in classes & 10 & 100 & 0 & 0 & 11 & 100 & 0 & 0 \\
\hline 10 & Is there any positive response from school toward your new idea & 10 & 100 & 0 & 0 & 11 & 100 & 0 & 0 \\
\hline 11 & Are you free to elaborate your ideas or views in studies & 10 & 100 & 0 & 0 & 11 & 100 & 0 & 0 \\
\hline 12 & Are teachers admit their mistakes after rechecking the papers & 10 & 100 & 0 & 0 & 11 & 100 & 0 & 0 \\
\hline 13 & Are you satisfied with content & 10 & 100 & 0 & 0 & 11 & 100 & 0 & 0 \\
\hline 14 & Is there any facility of guidance in selection of subjects by specialties & 0 & 0 & 10 & 100 & 4 & 36.4 & 7 & 63.6 \\
\hline 15 & Are you free to take books from library to enhance knowledge & 9 & 90 & 1 & 10 & 9 & 81.8 & 2 & 18.2 \\
\hline 16 & Are you free to participate in curricular activities & 10 & 100 & 0 & 0 & 11 & 100 & 0 & 0 \\
\hline 17 & Is there any rule for you to choose the subjects & 9 & 90 & 1 & 10 & 6 & 54.5 & 5 & 45.5 \\
\hline 18 & Are you free in selection of your teachers & 9 & 90 & 1 & 10 & 5 & 45.5 & 6 & 54.5 \\
\hline 19 & Are you satisfied with teaching learning methods & 10 & 100 & 0 & 0 & 11 & 100 & 0 & 0 \\
\hline 20 & Do you feel any extra burden of content & 0 & 0 & 10 & 100 & 1 & 9.1 & 10 & 90.9 \\
\hline
\end{tabular}

The students of 9 th class (100\%) disagreed and students of 10th class (63.6\%) disagreed with the statement that there was no guidance provided to them in selection of their subjects. Only 4 students of class 10th said that there is guidance on subject selection. The students agreed that they were free to take books from library to enhance their knowledge, only one students from class 9 and two students from class 10 expressed against it. The students $(100 \%)$ reported that they were free to take part in curricular activities. The students (9 out of 10 from class 9 and 6 out of 11 from class 10) explained that there was 
rule for them to choose the subjects, while others responded in negative. The students $(90 \%)$ of class 9 th narrated that they were free in selection of their teachers, whereas only $45.5 \%$ of 10 th class students said that they were free to choose teachers of their choice. The students $(100 \%)$ said that they were satisfied with the teaching methods. only one student of class 10 responded that they felt extra burden of content, all others did not agree with the burden of content item.

\section{Data Analysis of Observation Check List by Researchers}

Participant observation is often used in qualitative research. Participant observation is defined as a field strategy that simultaneously combines document analysis, interviewing of respondents and informants, direct participation and observation and introspection. Following is the analysis of the observation check list.

\begin{tabular}{|c|c|c|c|c|c|}
\hline \multirow[t]{2}{*}{ Sr. No. } & \multirow[t]{2}{*}{ Statements } & \multicolumn{2}{|c|}{ Yes } & \multicolumn{2}{|c|}{ No } \\
\hline & & $\mathrm{f}$ & $\%$ & $\mathrm{f}$ & $\%$ \\
\hline 1 & Does trust follow government curriculum & 1 & 100 & 0 & 0 \\
\hline 2 & Is the school following mix curriculum for quality education & 1 & 100 & 0 & 0 \\
\hline 3 & Are the learning objectives connected to individual education plan & 0 & 0 & 1 & 100 \\
\hline 4 & Is extra guidance provided to students for quality education & 1 & 100 & 0 & 0 \\
\hline 5 & According to subject/Syllabus need extra classes are conducted & 1 & 100 & 0 & 0 \\
\hline 6 & Regular tests are conducted & 1 & 100 & 0 & 0 \\
\hline 7 & Is only annual system followed & 0 & 0 & 1 & 100 \\
\hline 8 & Does teachers explain topic on daily basis & 1 & 100 & 0 & 0 \\
\hline 9 & Do the students feel free to select science subjects & 0 & 0 & 1 & 100 \\
\hline 10 & Do teachers use helping materials/guides for teaching & 1 & 100 & 0 & 0 \\
\hline 11 & Does institute provide question paper and answer sheets & 1 & 100 & 0 & 0 \\
\hline 12 & Are answer sheets rechecked by the head of marking for quality assurance & 1 & 100 & 0 & 0 \\
\hline 13 & Are strict invigilation rules followed for quality improvement & 1 & 100 & 0 & 0 \\
\hline 14 & Can the students receive and recheck their papers after checking & 1 & 100 & 0 & 0 \\
\hline 15 & Are students abilities strictly tested at the time of admission & 1 & 100 & 0 & 0 \\
\hline 16 & Can anybody get admission any time during the academic year & 0 & 0 & 1 & 100 \\
\hline 17 & Health services are provided to students & 1 & 100 & 0 & 0 \\
\hline 18 & Do the students feel free and enjoy coming to school & 1 & 100 & 0 & 0 \\
\hline 19 & Is there any students counselor is in school & 0 & 0 & 1 & 100 \\
\hline 20 & Are educational trips arranged for students & 1 & 100 & 0 & 0 \\
\hline 21 & Does the school arrange prizes for students to encourage them & 1 & 100 & 0 & 0 \\
\hline 22 & Are parent-teacher meetings arranged for quality education & 1 & 100 & 0 & 0 \\
\hline 23 & Does trust provide guidelines to parents to bring improvement & 1 & 100 & 0 & 0 \\
\hline 24 & Do trust provides education equipment's to teacher & 1 & 100 & 0 & 0 \\
\hline 25 & Are activity based learning and teachings followed & 1 & 100 & 0 & 0 \\
\hline 26 & Is there any research and science laboratory & 1 & 100 & 0 & 0 \\
\hline 27 & Is there any library equipped with education books/literature & 1 & 100 & 0 & 0 \\
\hline 28 & For quality education is there any club or society in your school & 1 & 100 & 0 & 0 \\
\hline 29 & Does trust engage students in curricular and co-curricular activities & 1 & 100 & 0 & 0 \\
\hline 30 & Do parents reflect satisfaction in Parent-teacher meetings & 1 & 100 & 0 & 0 \\
\hline 31 & Are different types of seating plans followed for healthy environment & 1 & 100 & 0 & 0 \\
\hline 32 & Does the school has colorful classrooms for healthy learning & 1 & 100 & 0 & 0 \\
\hline 33 & Do teachers use real materials display for better learning & 1 & 100 & 0 & 0 \\
\hline
\end{tabular}

Table 3 indicated the observation checklist data observed by the researchers. One researcher has served in the "Trust school", so it was decided to make him the participant 
observer in this research. In this way objective analysis of the on ground practices were also brought on paper. The table illustrates that in majority of the 33 item checklist, the things were in practice in the "Trust school". What was found interesting by the researcher was that the learning objectives were not connected to the individual learning plans. This could be because the teachers have to take classes on regular basis and their focus is on syllabus completion.

The researchers found that there was no student counselor who could help students in their selection of subject. This was strengthened by the observation that students were not free to select their subject. It was also noted that no one was allowed to take admission during the academic year. Health services were provided to the students and that is why students enjoyed and felt relaxed while coming to school. Educational trips and cocurricular activities were arranged by the schools to enhance the learning of the students. Parent teacher meeting was also arranged to inform the parents about quality education. A laboratory, library, and computer labs also existed for science, research, and computer students. A society was also active to ensure the quality of education in the school. The "Trust school" had colorful classrooms and administration also took keen interest in the operations of the school.

\section{Discussion}

The purpose of the study was to explore the quality of education in Trust School. Case study design was adopted to conduct this research. A main research question was formulated. How does The Trust School provide quality education? Subsidiary research questions were framed to answer the main research question. First subsidiary research question is enlisted below. Sub question one: What factors are identified in maintaining quality education in The Trust School? Since the sample comprised different segments, the discussion is made separately for each segment to identify the similarity and differences.

\section{Headmasters/Principals}

Following factors were identified by the headmasters/principals. The participants highlighted the following factors i.e. holistic child development, curriculum, strict recruitment process of qualified teachers, student teacher ratio, activity based teaching, modern and effective teaching methodology, good infrastructure, conducive environment, use of AV aids, modern curriculum, assessment of students performance, reinforcement of students, mentoring and reporting system, counselor for students, field trips, activity learning, active teaching, teaching methodology, moral training, admission test, selection of teachers on merit, attractive salary package, decision making, annual increment, free of cost training and workshops, seminars, pick and drop services, incentives, computer laboratory, library, curricular and extra-curricular, and participatory leadership. 


\section{Teachers}

Teachers including (9th class male and female, 10th class male and female, male and female class teachers of 5 th, 6 th, 7 th, 8 th, 9 th and 10th class) identified the following factors i.e. transport facility, opportunity for higher education, regular visit to other campus for quality education, computer courses, block printing, cooking courses, use of AV aids, use of different teaching methods for teaching, provision of books and teaching material, organization of workshops and seminars for teacher training, lesson planning, use of internet technology for teaching, Punjab textbook board curriculum, Oxford curriculum, strict checking and strict leave rules. Different teaching methods such active learning method in enhancing students performance is also identified in the literature (Khan, Majoka, Khurshid, \& Shah, 2017).

\section{Students}

The students of 9th and 10th class identified the following factors i.e. feedback to the students and their parents, satisfaction with teaching methodology of teacher, facilitation with educational resources, satisfaction with teaching content, discussion in classroom are the factors also supported and evident in the literature (Abdullah \& Bhatti, 2018; Colbert \& Arboleda, 2016). Other factors included positive response towards new idea and its elaboration, friendly environment, satisfaction with book content, guidance in subject selection, resourceful library, curricular and co-curricular activities, feedback on teachers, satisfaction with teaching methodology and supportive learning environment.

\section{Observations of Researchers}

The researchers identified the following factors, i.e. Punjab textbook board and oxford curriculum, attainment of learning objectives, guidance for the students, regular test system, extra classes for weak students (Damşa \& Nerland, 2016), freedom in subject selection, provision of helping and teaching material, fair invigilation, feedback to the students and their parents, entrance test for admission, provision of health services, educational trips, use of AV aids, different teaching methodology for every topic, counselor for students, prizes to reinforce students, activity based teaching, research and science laboratory, resourceful library, curricular and extra-curricular activities, and supportive environment. Different teaching techniques according to need of the lesson and students is a practice in schools these days (Qureshi \& Jilani, 2013).

\section{Second Subsidiary Question}

What is the role of teacher training program for enhancing the quality education? The headmasters explained the role of teacher training for enhancing quality education by identifying the following program. Strict recruitment process is followed to select the teacher. Teachers are given orientation about different rules and regulation of the school after being selected. They are given induction training. Refresher courses are organized to 
train the teachers in school from time to time. Workshops and seminars are also conducted in school for teacher training. This is an essential feedback element in quality drives cases and supported in the literature by Abdullah and Bhatti (2018); Winstone, Nash, Parker, and Rowntree (2017).

The teachers explained that teacher training help them in enhancing their professional skills. Computer courses, refresher courses, training workshops, seminars, and symposiums are conducted to train the teachers. Teachers are instructed to present on daily basis because there is no provision of leave for teachers. Teachers are instructed to maintain their attendance and they are asked to cover course content in required time. Different workshops related to assessment and evaluation is also organized to train the teachers. These teacher related strategies are in line with the findings of (Sarin, 2015).

The students were satisfied with the quality of education in "Trust school". The quality of education is only possible if the teachers are well trained (Alvi, Butt, \& Khurshid, 2013) . Different training workshops and seminars are conducted in the school to train the teachers. School administration ensures the hundred percent attendances of the teachers. Leave rules are very strict. Therefore, a teacher has to inform the higher authorities of school before he/she is going on leave. Educational trips are arranged for teachers to other campuses of different schools. Teachers may interact with other professionals during these educational trips to enhance their communication and professional skills. These are in-line with the findings of (Scager, Akkerman, Pilot, \& Wubbels, 2017).

The researchers also identified that teaching training was an important aspect in "Trust school". The teachers had to go through strict recruitment process for final selection. Induction training is given to the teachers which encompasses comprehensive briefing about all rules and regulation of school. Seminars and workshops were conducted to train the teachers. The development of teachers' communication skills is main focus of this training.

\section{Third Subsidiary Question}

How does the administration of "Trust school" ensure quality education among people and students? The administration of the school ensures quality education through training of teachers. Teachers need to inform the administration before taking leave. A substitute teachers take the class if the class teacher is absent on that particular day. Teachers visit and interact with professionals of other campuses of "Trust school" to enhance their professional skills. The "Trust school" follows the board pattern. Teachers need to finish the course content on time. The school administration regularly arranged meetings with parents. Parents and societal input and engagement are considered important for schools nowadays. This is consistent with the findings of (Qureshi \& Jilani, 2013).

The regular attendance of the teachers and students is ensured through strict process. Teachers have to develop lesson plans before delivering the lecture in the class. The performance of the students is discussed with parents in these meetings. This collaborative learning and participation of teachers-parents also adds to quality education, as presented in the findings of (Damşa, 2014). Different AV aids are used during the delivery of the lecture. Mixed curriculum (Punjab Textbook board and Oxford) is offered in the school to 
maintain the balance in quality of education. Teaching methods are also used according to the nature of the topic. Seminars and workshops are conducted to train the teachers. Refresher courses are also arranged in school for training of teachers. In this way the questions were answered and objectives of the research were achieved by the researchers.

\section{Conclusion}

A case study design was used to investigate the quality of education provided by The Trust School (TEDDS). Deserving students get scholarship to study in The Trust School. The students of TEDDS get an opportunity to study in Lahore University of Management Sciences (LUMS) based on their outreach program. So far 39 students have been selected and studied in LUMS. This also validates the quality education provisions in TEDDS. The teacher recruitment process is very rigorous. Therefore, qualified teachers are appointed in The Trust School after screening, written tests, and panel interviews. This helps in the teaching-learning and active learning method in the classroom settings. The organization of The Trust School is very structured because everything is well planned, formalized and standard operating procedures (SOPs) are followed. Principals/ Headmasters are available to look into every academic and managerial problem. According to DiCicco-Bloom and Crabtree (2006) this is an important factor in assuring quality in educational institutions. They solve each problem immediately. Quality of education is not affected in this way. Subject specialists who have experience in their field are appointed after systematic procedure to ensure the quality of education. This gives the students an opportunity to learn through inquiry based and it certainly adds to the quality of education (Damşa \& Nerland, 2016).

Different workshops, seminars and refresher courses are organized to train the teachers. The purpose of these kinds of activities is to equip and train the teachers with modern knowledge and teaching techniques (Akram \& Shah, 2018). Curricular and co-curricular activities are organized in The Trust School to enhance the creativity of teachers and students. The participants of the study identified the following indicators of quality of education i.e. facilities provided by school, teacher training, teaching methodology, curriculum and strict leave rules. The results produced by the "Trust school" are also evident that they are offering quality education. Moreover, they offer full scholarships to the needy students. The normal fee structure is also affordable for the students' families. In this minimal fee package Trust is providing par excellence quality education. Trust school in comparison to the Beacon house school system (Alvi et al., 2013) and Danish school that is claimed to be quality driven (Qureshi \& Jilani, 2013) has achieved academic quality success as well as business success in terms of expansion both in number of students and in number of branches, in a relatively lesser period of time.

\section{Recommendations}

Based on the above discussion and conclusion, following recommendations may be drawn. The school may provide the traveling facility to their staff. They may reach the school in 
time and contribute towards the development of school. Furthermore, the school may provide opportunities to their staff for getting higher education. The performance of the staff may be increased if they are highly qualified.The school may arrange different visits to other branches or campuses of school to train their teaching staff. A framework may be initiated for struck off from the school and every individual may follow it.

Substitute teachers may be arranged for teaching when the class teachers are on leave. There may be no effect on the studies of the students in this way. 


\section{References}

Abdullah, N. A., \& Bhatti, N. (2018). Failure in quality of academic performance of students in public sector schools of Sheikhupura. Journal of Education and Educational Development, 5(2), 289-305.

Akram, M., \& Shah, A. A. (2018). Predicting student achievement through organizational learning culture. Journal of Education and Social Sciences, 6(2), 15-26.

Alvi, S., Butt, A. N., \& Khurshid, A. (2013). Beaconhouse school system (BSS) restructuring. Asian Journal of Management Cases, 10(2), 113-124.

Arshad, M. (2003). Attitude of teachers of higher education towards their profession. Unpublished M. Phil. Thesis. AIOU, Islamabad, Pakistan.

Basit, T. (2003). Manual or electronic? The role of coding in qualitative data analysis. Educational Research, 45(2), 143-154.

Campbell, T. (1997). Technology, multimedia, and qualitative research in education. Journal of Research on Computing in Education, 30(2), 122-132.

Colbert, V., \& Arboleda, J. (2016). Bringing a student-centered participatory pedagogy to scale in Colombia. Journal of Educational Change, 17(4), 385-410.

Creswell, J. W. (2012). Educational Rsesearch: Planning. US: Sage Publications.

Damşa, C. I. (2014). The multi-layered nature of small-group learning: Productive interactions in object-oriented collaboration. International Journal of Computer-Supported Collaborative Learning, 9(3), 247-281.

Damşa, C. I., \& Nerland, M. (2016). Student learning through participation in inquiry activities: Two case studies in teacher and computer engineering education. Vocations and Learning, 9(3), 275-294.

Delyser, D. (2008). Teaching qualitative research. Journal of Geography in Higher Education, 32(2), 233-244.

Denzin, N. K., \& Lincoln, Y. S. (2011). The Sage handbook of qualitative research. US: Sage Publications.

DiCicco-Bloom, B., \& Crabtree, B. F. (2006). The qualitative research interview. Medical Education, 40(4), 314-321.

Elliott, M., \& Williams, D. (2001). Paradoxes of qualitative research. Counselling and Psychotheraphy Research, 1(3), 181-183.

Franklin, C. (1997). Learning to teach qualitative research: Reflections of a quantitative researcher. Marriage \& Family Review, 24(3-4), 241-274.

Iqbal, A. (2004). Problems and prospects of higher education in Pakistan (Unpublished doctoral dissertation).

Kalam, A. (2003). Attempting for excellence in higher education. Paper presented at National Conference on Quality Assurance in Education in Pakistan. Pakistan Institute of Quality Control. Lahore.

Khan, K., Majoka, M. I., Khurshid, K., \& Shah, S. M. H. (2017). Impact of active learning method on students academic achievement in physics at secondary school level in Pakistan. Journal of Education and Educational Development, 5(2), 134-151.

LeCompte, M. D. (2000). Analyzing qualitative data. Theory into Practice, 39(3), 146-154. 
Liston, D. P. (2013). Reconsidering university-based teacher education. Curriculum and Teaching Dialogue, 14(1), 15-20.

Malik, S., \& Courtney, K. (2011). Higher education and women's empowerment in Pakistan. Gender and Education, 23(1), 29-45.

McCowan, T. (2013). Education as a human right: Principles for a universal entitlement to learning. UK: A\&C Black.

McLean, A. J., Bond, C. H., \& Nicholson, H. D. (2015). An anatomy of feedback: A phenomenographic investigation of undergraduate students' conceptions of feedback. Studies in Higher Education, 40(5), 921-932.

Mehrotra, S. (2006). Reforming elementary education in India: A menu of options. International Journal of Educational Development, 26(3), 261-277.

Qureshi, Z. I., \& Jilani, H. I. (2013). The Daanish schools: To expand or not to expand. Asian Journal of Management Cases, 10, 145-162.

Roberts, C. (2013). Ethics in qualitative research: Controversies and contexts. Qualitative Research in Psychology, 10(1), 98-103.

Saeed, K. (2003). Quality in higher education and universities. Paper presented at National Conference on Quality Assurance in Education in Pakistan. Pakistan Institute of Quality Control Lahore.

Sarin, M. N. (2015). Quality education for all? A case study of a New Delhi government school. Policy Futures in Education, 13(3), 360-374.

Scager, K., Akkerman, S. F., Pilot, A., \& Wubbels, T. (2017). Teacher dilemmas in challenging students in higher education. Teaching in Higher Education, 22(3), 318-335.

Whitty, G. (2000). Teacher professionalism in new times. Journal of In-service Education, 26(2), 281-295.

Winstone, N. E., Nash, R. A., Parker, M., \& Rowntree, J. (2017). Supporting learners' agentic engagement with feedback: A systematic review and a taxonomy of recipience processes. Educational Psychologist, 52(1), 17-37. 